\title{
Forest fragmentation in the temperate zone and its effects on migratory songbirds
}

\author{
SCOTT K. ROBINSON and DAVID S. WILCOVE
}

\section{Summary}

Although much attention has been paid to the impacts of tropical deforestation on populations of Neotropical migrants, fragmentation of breeding habitat may be an equally serious problem for many of these birds. Populations of many migrant songbirds have been declining in recent decades, especially within small woodlots. Censuses from woodlots of different sizes also consistently show that many migrant songbirds are area-sensitive, i.e. they are absent from all but the largest woodlots in a region. In contrast, long-term censuses from large, unfragmented forests show few consistent patterns of decline in Neotropical migrants. Population declines are therefore linked to forest fragmentation because they are most pronounced in small, isolated woodlots.

Fragmentation leads to significant increases in nest predation and cowbird Molothrus spp. parasitism, the two most important causes of population declines and area-sensitivity. Predation and nest-parasitism rates are higher in small woodlots and along the edges of larger tracts than in the interior of large tracts. Data from fragmented forests in the American Midwest show that reproductive rates of several forest species are probably well below levels necessary to compensate for adult mortality. Among Wood Thrushes Hylocichla mustelina nesting in central and southern Illinois, for example, $89-100 \%$ of nests contain cowbird eggs (average of 2.2-4.6 cowbird eggs/nest) and nest-predation rates range from 50 to $96 \%$. For the Wood Thrush and other forest songbirds, fragmented landscapes may be population sinks with populations sustained by immigration from larger, unfragmented forest tracts. These data emphasize the importance of protecting large, unfragmented forests for breeding habitat. We need far better data on dispersal rates and distances, fecundity and survival rates before we can determine what levels of predation and parasitism migratory birds can tolerate.

The effects of silvicultural practices such as clear-cutting and selective logging on migratory songbirds may depend upon the landscape context. Preliminary evidence from a fragmented national forest in the Midwest suggests that selective logging can have relatively little impact on forest songbirds. We tentatively propose that low-volume selective logging be used as an alternative to clear-cutting. Logging roads should be closed and revegetated soon after harvest, and rotation times should be lengthened to permit regeneration of large, old trees.

A pesar de la atención prestada al impacto de la deforestación tropical sobre las poblaciones de aves migradoras neotropicales, la fragmentación del hábitat de 
cría puede ser un problema igualmente serio para muchas de estas aves. Las poblaciones de muchos pájaros migradores han disminuido en las últimas décadas, especialmente en pequeñas parcelas de bosque. Los censos en parcelas de diferente tamaño también prueban que muchos pájaros migratorios son dependientes de la superficie de la párcela, es decir, que solo están presentes en las de mayor tamaño en una misma región. Por el contrario, censos continuados en bosques grandes y no fragmentados señalan que no existe un patrón claro de declive en los migrantes neotropicales. Los declives de población están, por lo tanto, ligados a la fragmentación del hábitat, puesto que son más pronunciados en parcelas pequeñas y aisladas.

La fragmentación conduce a un significativo incremento en la predación de nidos y en el parasitismo en especies de Molothrus, las dos razones principales del declive poblacional y de la susceptibilidad al tamaño de parcela. Las tasas de predación y parasitismo de nidos son más elevadas en parcelas pequeñas y en los bordes de bosques grandes que en el interior de éstos. Las investigaciones realizadas en bosques fragmentados del Medio Oeste americano indican que las tasas reproductivas de varias especies forestales están muy por debajo del nivel necesario para compensar la mortalidad adulta. Por ejemplo, un $89-100 \%$ de los nidos de Hylocichla mustelina en el centro y sur de Illinois contienen huevos de Molothrus (una media de 2.2-4.6 huevos por nido) y las tasas de predación de nido varían entre un 50-96\%. En medios fragmentados, las poblaciones de H. mustelina y otras aves forestales se mantienen gracias a la inmigración desde bosques más grandes y no fragmentados. Estos datos destacan la necesidad de proteger grandes áreas boscosas no fragmentadas como hábitat de cría. Se necesitan más datos sobre tasas de dispersión y distancia, fecundidad y tasas de supervivencia antes de poder determinar que niveles de predación y parasitismo pueden tolerar las aves migratorias.

Los efectos de ciertas prácticas silvícolas, tales como el aclareo y las cortas selectivas, sobre las aves migratorias dependerán del contexto general del medio. Los datos preliminares de un bosque nacional fragmentado en el Medio Oeste sugieren que las cortas selectivas pueden tener un impacto relativamente bajo en las aves. Proponemos provisionalmente que se realicen cortas selectivas de bajo volumen como alternativa al aclareo. Las pistas para sacar madera deberían ser cerradas y replantadas después de la corta y los ciclos de rotación deberían alargarse para permitir la regeneración de los árboles más grandes y viejos.

\section{Introduction}

Declines in breeding populations of warblers, vireos, thrushes, flycatchers and other Neotropical migrants in the United States and Canada have generated much interest among scientists and conservationists (Terborgh 1989, Finch 1991, Hagan et al. 1992). Although much of the attention has focused on the impact of winter habitat loss, there is growing evidence that the destruction and fragmentation of breeding habitat is also a serious problem (Holmes et al. 1986, Wiens 1989, Wilcove and Robinson 1990). In this paper, we review the evidence that populations of Neotropical migrants have indeed declined, discuss how these declines relate to forest fragmentation on the breeding grounds, and offer 
recommendations for the management of forests in light of these concerns. We focus exclusively on forest species that breed in eastern North America, but acknowledge that migratory birds associated with other habitats may also be adversely affected by fragmentation (e.g. Elliott 1978, Brown and Dinsmore 1986, Johnson and Temple 1986).

\section{Evidence for declines}

Most veteran birdwatchers throughout the eastern United States have a strong impression that Neotropical migrants have declined substantially. While definitive proof remains elusive (Finch 1991, Hagan et al. 1992), three lines of evidence point to real population declines of Neotropical migrants.

First, long-term census data from about a dozen small woodlots, some going back as far as the 1940s, show very similar patterns (Askins et al. 1990, Wilcove and Robinson 1990). In each of these small woodlots, Neotropical migrants have declined precipitously, whereas populations of year-round residents and short-distance migrants have remained stable or increased. On Cabin John and Plummers islands in Maryland, for example, breeding populations of Neotropical migrants have declined by roughly 50\% since the 1940s (Briggs and Criswell 1979, Johnston and Winings 1987). In each woodlot, several species have vanished (e.g. Kentucky Oporornis formosus and Hooded Warblers Wilsonia citrina) and others have declined by at least $70 \%$ (e.g. Red-eyed Vireo Vireo olivaceus, Ovenbird Seiurus aurocapillus) since the censuses began. In contrast to these small woodlots, the few large forest tracts that have been surveyed over long periods of time show no consistent patterns. In the Smoky Mountains of Tennessee and North Carolina, for example, Wilcove (1988) found no evidence of overall declines in Neotropical migrants between the late 1940s and the early 1980s. In the Hubbard Brook Experimental Forest in the White Mountains of New Hampshire, Holmes et al. (1986) found that long-term population trends of Neotropical migrants were best attributed to successional changes. On the whole, then, populations of Neotropical migrants appear to be faring better in larger tracts (Finch 1991, Sherry and Holmes 1992).

The second line of evidence for population declines comes from bird surveys in woodlots of different sizes. In various regions of eastern North America, some species of Neotropical migrant are consistently absent from all but the largest woodlots. This pattern holds for the East (Whitcomb et al. 1981, Lynch and Whigham 1984, Askins et al. 1987, Robbins et al. 1989a) and the Midwest (Bond 1957, Ambuel and Temple 1982, Kendeigh 1982, Howe 1984, Hayden et al. 1985, Blake and Karr 1987). These "area-sensitive" species are absent from many woodlots where there appear to be suitable habitat and sufficient area to contain many territories (Lynch and Whigham 1984, Robbins et al. 1989a). Year-round residents and short-distance migrants, on the other hand, are much less area-sensitive (Robbins et al. 1989a). Gibbs and Faaborg (1990) also found that a higher percentage of male Ovenbirds (a Neotropical migrant) were unmated in small woodlots compared to large forest tracts.

The third line of evidence for widespread population declines comes from regional roadside (Breeding Bird Survey) censuses performed under the direction of the U.S. Fish and Wildlife Service since 1966. Until the late 1970s, these 
surveys detected no significant declines among most Neotropical migrants (Robbins et al. 1986). During the 1980s, however, they began to pick up statistically significant regional declines (Robbins et al. 1989b, reviewed in Finch 1991 and Askins et al. 1990). The significance of these declines is not, however, universally accepted. James et al. (1992), for example, argued that many species (e.g. Kentucky Warbler) are declining only in portions of their ranges.

Several conclusions can be drawn from the literature on population declines (Askins et al. 1990, Wilcove and Robinson 1990, Finch 1991). We feel there is good evidence that Neotropical migrants are declining in at least certain areas. These declines are strongly linked to forest fragmentation on the breeding grounds because they are most pronounced in small, isolated woodlots. Clearly, destruction of wintering habitat is a significant problem (see Robbins et al. $1989 \mathrm{~b}$ ), but factors associated with the breeding grounds are critically important, too. This assertion is strongly supported by the finding of Sherry and Holmes (1992) that year-to-year population changes in American Redstarts Setophaga ruticilla in a large, unfragmented forest were most strongly linked with the previous year's reproductive success. Sherry and Holmes (1992) argue that events on the breeding grounds may be even more important in determining overall population trends in fragmented landscapes, where reproductive success is generally much lower than in large contiguous forests (see below).

\section{How does fragmentation of breeding habitat lead to extinction?}

Fragmentation causes population declines through many mechanisms, each of which probably affects individual species differently. Here we briefly review some of the mechanisms that have been proposed and focus on the two we believe to be most important: nest predation and brood-parasitism.

\section{Dispersal and colonization}

Some Neotropical migrants might have difficulty dispersing to and colonizing isolated woodlots. Lynch and Whigham (1984) found that more isolated woodlots had fewer Neotropical migrants than less isolated woodlots of comparable size and vegetation. Blake and Karr (1987) and Robinson (1988, 1992), on the other hand, found that extremely isolated woodlots in the Midwest contained more forest-interior Neotropical migrants than expected based on size or structure alone. In such isolated woodlots, dispersing migrants may have no other nearby alternative habitats; they essentially face a choice between farm fields or forest fragments.

Further evidence for the importance of habitat isolation comes from ongoing studies at the Connecticut Arboretum (Askins and Philbrick 1987, Askins et al. 1987). Between 1953 and 1976, breeding populations of Neotropical migrants within the arboretum declined as new roads, shopping centres and a highway interchange were constructed nearby. More recently, however, extensive areas around the study site that were old fields in 1953 have grown into young forest, which has reduced the isolation of the study site. These young forests now contain breeding populations of forest-dwelling Neotropical migrants, and cen- 
suses from 1982 to 1985 show an increase in numbers of Neotropical migrants within the arboretum, perhaps because there are nearby sources of colonists.

There is a growing literature on landscape-level interactions among subpopulations connected by dispersal (a network of interacting subpopulations is termed a "metapopulation") (Pulliam 1988, Hanski and Gilpin 1991, Freemark and Collins 1992, Ray et al. 1991, Villard et al. 1992). Neotropical migrants living in a landscape of forest fragments and developed lands are best viewed as consisting of a set of metapopulations. Recolonization of small woodlots after populations have "winked out" (Villard et al. 1992) may be determined by the proximity of nearby source populations, where reproductive rates are high enough to produce a surplus (Howe et al. 1991, Pulliam 1991), and on the availability of alternative habitats for dispersers (Blake and Karr 1987). Recolonization may also be strongly influenced by the presence of conspecifics in a woodlot (Stamps 1988, Smith and Peacock 1990, Ray et al. 1991), because species that form territorial aggregations within available habitat (e.g. the Least Flycatcher Empidonax minimus: Sherry and Holmes 1988) may not colonize small woodlots without the auditory or visual cues provided by a stable core of adults that return year after year (Smith and Peacock 1990). The role of conspecific attraction in Neotropical migrants is a potentially fruitful area for further study (Ray et al. 1991). Until we understand more about the scale of dispersal, however, it will be difficult to evaluate metapopulation models.

\section{Forest succession}

Evidence exists that forest succession may be an important factor behind the changes seen in the Hubbard Brook Experimental Forest in New Hampshire where several species associated with mid-successional vegetation have all but disappeared (Holmes et al. 1986). Virtually all of the forests of eastern North America were cut within the last 50-150 years; for this reason, some changes in bird composition can be expected as the regenerating forests age and midsuccessional tree species are replaced by shade-tolerant species characteristic of old-growth forests. The "gap-phase dynamics" (Pickett and White 1985) characteristic of old-growth forests may result in very different bird communities from those of the comparatively even-aged forests that now cover most of North America (Blondel 1991). The gaps created by treefalls and blowdowns might result in the return of some of the early and mid-successional species that currently depend on clear-cuts and abandoned agricultural land. Unfortunately, we lack sufficient intact old-growth forests in eastern North America to undertake comparative studies.

\section{Food resources}

The availability of food may differ systematically with forest size, but this topic remains largely unexplored. Although we are aware of no evidence, it seems distinctly possible that carbon monoxide and other rural/urban chemicals may have a far greater impact on the insects of small forest fragments than on insects in forest wilderness. Whether this translates into a shortage of food for Neotrop- 
ical migrants in small woodlots is unknown. We know little, however, about the extent to which food supply limits avian productivity.

\section{Critical microhabitats}

Small forest tracts may lack the full range of microhabitats typical of larger tracts. A small woodlot, for example, may not have any streams and cooler ravines, which are used by some birds (e.g. Acadian Flycatcher Empidonax virescens and Louisiana Waterthrush Seiurus motacilla), or it may lack the steep slopes necessary for species such as the Worm-eating Warbler Helmitheros vermivorus (Bond 1957, Whitcomb et al. 1981, Robinson 1988, 1992). Similarly, species that use two or more different microhabitats over the course of the breeding season (Root 1967, Karr 1982) may not be able to survive in fragments that lack one of these microhabitats. Availability of predator-free species-specific nest sites may also dictate the presence of certain species (Martin 1992). Kentucky Warblers, for example, require dense ground cover to hide their open-cup nests from predators (Hands et al. 1989). Ovenbirds, on the other hand, prefer relatively flat wooded areas with open ground layers where they place their domed nests (Hands et al. 1989). Woodlots with open ground layers in Illinois generally lack Kentucky Warblers, whereas those with dense ground cover generally lack Ovenbirds. Lynch and Whigham's (1984) finding that each species responds to different structural and floristic characteristics of the vegetation may therefore reflect both foraging and nesting site requirements. In summary, we think the absence of critical microhabitats in some small woodlots may explain the absence of certain Neotropical migrants. But in places like Cabin John Island or Plummers Island, where sizeable populations once existed, other factors must be sought to explain their disappearance. Moreover, many declining forestinterior birds tolerate a wide variety of forest types (Bond 1957, Blake and Karr 1987, Askins et al. 1987). For these species, factors other than microhabitat availability may dictate their population dynamics.

\section{Nest predation and brood-parasitism}

Fragmentation has repeatedly been shown to lead to higher rates of nest predation and brood-parasitism, which we believe are the major causes of population declines.

Nest-predation rates are higher in small woodlots than in large forest tracts, and are especially high in suburban fragments compared with rural ones (Wilcove 1985, Wilcove et al. 1986, Robinson 1988; review in Wilcove and Robinson 1990). There are three probable reasons for these trends. First, in the absence of top predators (which, as a rule, do not thrive in human-dominated landscapes), medium-sized "mesopredators" such as raccoons often become very abundant in fragmented landscapes (Soulé et al. 1988). Because mesopredators often depredate bird eggs and nestlings, predation rates in small fragments may be unusually high (Wilcove 1985). Second, populations of many nest predators are unusually high in fragmented landscapes, as in suburbs, where humans provide abundant supplemental food either intentionally (i.e. bird seed 
Table 1. Impact of cowbird parasitism on fledging success in nests that escape predation, Shawnee National Forest, 1989 and 1990

\begin{tabular}{lccc}
\hline & \multicolumn{3}{c}{ Host young fledged/successful nest } \\
\cline { 2 - 4 } Host Species & Unparasitized & Parasitized & $\%$ Reduction \\
\hline Acadian Flycatcher & 2.4 & 0.4 & -83 \\
Wood Thrush & 3.0 & 1.4 & -53 \\
Worm-eating Warbler & 4.2 & 1.7 & -60 \\
Kentucky Warbler & 3.1 & 0.5 & -84 \\
Louisiana Waterthrush & 4.5 & 1.2 & -73 \\
\hline
\end{tabular}

for jays, grackles, etc.) or unintentionally (i.e. food scraps and other garbage "stolen" by raccoons, opossums, etc.). Moreover, people regularly maintain two predators - dogs and cats - as pets (Wilcove 1985). Third, there is abundant evidence that nest-predation rates are higher along edges than in the interior of woodlots, a pattern that holds in different areas (Gates and Gysel 1978, Angelstam 1986, Wilcove et al. 1986, Ratti and Reese 1988, Small and Hunter 1988, Temple and Cary 1988, Yahner and Scott 1988; reviewed in Yahner 1988). In severely fragmented landscapes, where the proportion of edge to interior habitats is high, there may be few refuges where predation rates are low enough to allow sufficient reproduction (Robinson 1988, 1992). High populations of deer, which benefit from forest fragmentation, may increase predation on ground nests because deer remove most of the vegetation near the ground layer (Alverson et al. 1988), exposing the nests to predators.

The geographical distribution and abundance of the brood-parasitic Brownheaded Cowbird Molothrus ater, an obligate brood-parasite, increased greatly in North America during the last century as forests were converted to farm fields (Mayfield 1965, Rothstein 1975, Brittingham and Temple 1983, Trine et al. in press). Also, waste grain in farm fields may have increased winter survivorship. We suspect, therefore, that most of the more than 200 cowbird host species are experiencing increased cowbird parasitism (Mayfield 1965, 1977, Trine et al. in press). Because parasitism severely reduces host reproductive output (Table 1 ), high levels of brood-parasitism have the potential to cause local population extinctions (Mayfield 1977, May and Robinson 1985). As is the case with nest predation, brood-parasitism rates are higher near edges than in the interior of large forest tracts (e.g. Gates and Gysel 1978, Brittingham and Temple 1983, Temple and Cary 1988).

Cowbirds appear to prefer searching for host nests near the edges of forest tracts, possibly because edges are generally closer to the pastures and farmlands where they feed (Rothstein et al. 1984), and edges may contain a higher density of nests (Gates and Gysel 1978). Brittingham and Temple (1983) and Temple and Cary (1988), however, found that parasitism rates are also higher near "internal" edges around small ( $\leqslant 0.3 \mathrm{ha})$ openings within a forested landscape. Cowbirds therefore may be more efficient at searching for nests in more open areas such as those along forest edges (Brittingham and Temple 1983). Fragmented landscapes should have high levels of nest parasitism because small woodlots are dominated by edge habitats. 
Table 2. Cowbird parasitism levels of forest-dwelling Neotropical migrants in two sites in Illinois

\begin{tabular}{lccccc}
\hline \multirow{2}{*}{ Species } & \multicolumn{2}{c}{ Lake Shelbyville $^{1}$} & & \multicolumn{2}{c}{ Shawnee National Forest } \\
\cline { 2 - 3 } & $\begin{array}{c}\text { \% Para- } \\
\text { sitized (n) }\end{array}$ & $\begin{array}{c}\text { Cowbird eggs/ } \\
\text { parasitized nest }\end{array}$ & & $\begin{array}{c}\% \text { Para- } \\
\text { sitized (n) }\end{array}$ & $\begin{array}{c}\text { Cowbird eggs/ } \\
\text { parasitized nest }\end{array}$ \\
\hline Acadian Flycatcher & $50(2)$ & 1.0 & & $50(119)$ & 1.2 \\
Wood Thrush & $100(19)$ & 4.6 & & $89(83)$ & 3.2 \\
Red-eyed Vireo & - & - & & $100(4)$ & 3.0 \\
Louisiana Waterthrush & $50(2)$ & 1.0 & & $25(4)$ & 2.0 \\
Worm-eating Warbler & - & 50 & & $(8) 1.5$ & \\
Ovenbird & $40(5)$ & 2.0 & & - & - \\
Kentucky Warbler & $33(6)$ & 3.0 & & $53(32)$ & 1.8 \\
Summer Tanager & $100(6)$ & 3.8 & & $100(4)$ & 3.3 \\
\hline
\end{tabular}

${ }^{1}$ Data from Robinson (1992).

${ }^{2}$ Data from 1989 only, all three study areas combined.

\section{Landscape-level variation in nest predation and parasitism}

Limited data from the small woodlots around Lake Shelbyville, central Illinois (Robinson 1992), show that severely fragmented landscapes can act as population sinks for Neotropical migrants due to high levels of brood-parasitism and nest predation (Table 2). For species such as the Wood Thrush, annual reproduction is so low ( $<0.5$ fledglings/territory/year) that it is unlikely to compensate for adult mortality (Robinson 1992; see also May and Robinson 1985 and Temple and Cary 1988 for a discussion of population modelling). The primary value of small woodlots may be as migratory stopovers in otherwise hostile landscapes (Moore and Kerlinger 1987).

The proportion of Neotropical migrants nesting in small woodlots, however, may be small relative to the proportion nesting in larger forests such as those in national forests and other public lands. How are migrants faring in these less fragmented forests? A study of avian nesting success in moderately fragmented landscapes is under way in the Shawnee National Forest (SNF) of southern Illinois (S.K.R. unpublished data). The 104,000-ha SNF consists mostly of small $(<2,500 \mathrm{ha})$ tracts interspersed with numerous private inholdings and farms. No sections of this forest are more than $1 \mathrm{~km}$ from an edge. Intensive studies of the nesting success of Neotropical migrants in the western section of SNF indicate that cowbird parasitism (Table 2, Figure 1) and nest-predation levels (Figure 2) are high throughout the forest, at least for some species. The Wood Thrush, for example, suffered $80-100 \%$ parasitism rates even $>400 \mathrm{~m}$ from edges (Figure 1) and most nests were multiply parasitized (Figure 1). Acadian Flycatchers suffered lower levels of nest-parasitism than Wood Thrushes (Figure 1), but the consequences of parasitism may be equally severe because parasitized flycatcher nests seldom produce any host young (see Table 1). C. L. Trine (unpublished data) has found that the removal of Wood Thrush eggs by cowbirds is the major cost of parasitism for this species, because Wood Thrushes can raise both their own and cowbird nestlings in parasitized nests (Table 1).

Vulnerability to cowbird parasitism varies considerably among species in SNF (Table 2, S.K.R. unpublished data). Some species (e.g. Yellow-breasted Chat Icteria virens, Louisiana Waterthrush, Eastern Phoebe Sayornis phoebe) largely 

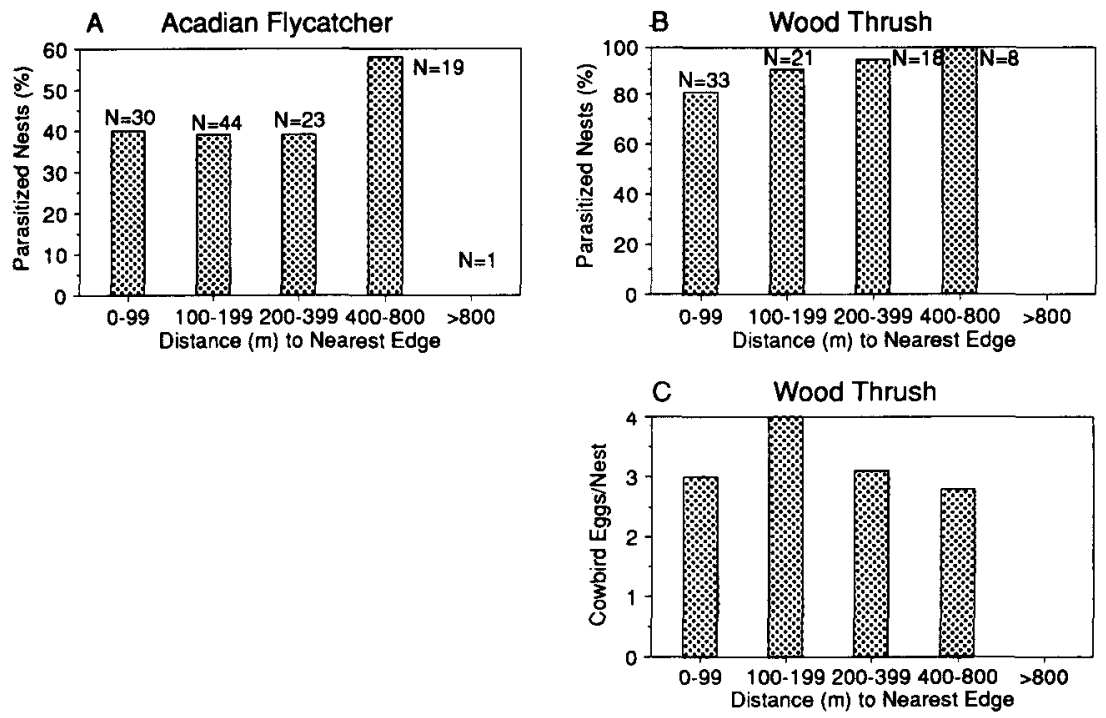

Figure 1. Parasitism levels in relation to distance to nearest edge of an opening of $\geqslant 0.2$ ha. Data include all nests found in three Shawnee National Forest study sites in 1989 .
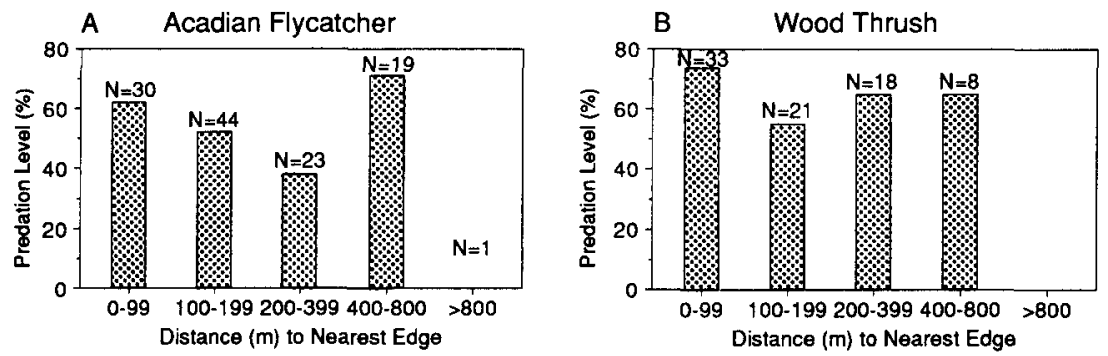

Figure 2. Predation rates in relation to distance to nearest edge. Data include all nests found in three Shawnee National Forest study sites in 1989. Predation rates calculated using the Mayfield (1975) method.

escape parasitism (S.K.R. unpublished data). These species either reject cowbird eggs (Rothstein 1975) or nest in cavity-like sites that are hidden from or inaccessible to cowbirds. Species that suffer moderate (30-50\%) parasitism levels (e.g. Worm-eating and Kentucky warblers) tend to be much more abundant and widespread than those suffering high $(\geqslant 75 \%)$ parasitism levels (e.g. Red-eyed Vireo, Hooded Warbler and Summer Tanager Piranga rubra) (S.K.R. unpublished data). The defences that allow some species and nests to escape parasitism are an area of active current research.

One surprising discovery is that nest-predation rates in SNF were not correlated with distance to edge (Figure 2). Predation rates vary considerably among species, years and sites (S.K.R. unpublished data), but most species experience 50-80\% nest losses to predation throughout the forest, a value much higher than the 20-40\% predation rates considered typical (Ricklefs 1973). A few species, such as the Louisiana Waterthrush, which builds cavity-like nests, and 
the Eastern Wood-Pewee Contopus virens, which aggressively defends its nests against predation, suffer relatively low $(<40 \%)$ predation rates in the SNF (S.K.R. unpublished data).

Results from SNF therefore strongly suggest a forest ecosystem in which cowbirds and nest predators are at "saturation" level. In this moderately fragmented landscape, there are no apparent forest-interior refuges from high levels of cowbird parasitism and nest predation as there are in the less fragmented forests of Wisconsin (Temple and Cary 1988). Some species may be surviving because they hide or defend their nests well; but several, including Wood Thrush, Hooded Warbler and Summer Tanager, are unlikely to be producing enough young to compensate for adult mortality (C. L. Trine and S.K.R. unpublished data). SNF may therefore be a major population sink for some species. Management plans for improving the nesting success of Neotropical migrants in SNF will have to take into consideration interspecific differences in susceptibility to nest predation and parasitism.

Evidence that forest fragmentation is responsible for the low nesting success of migrants in the SNF comes from studies of Neotropical migrants in less fragmented landscapes. In the extensively forested Ozark region of southern Missouri, Neotropical migrants nesting in primarily $(85-90 \%)$ forested landscapes suffer less than $5 \%$ parasitism rates and low $(<60 \%)$ nest-predation rates (J. Faaborg and R. L. Clawson pers. comm.). Similarly, in the more extensive Hoosier National Forest of nearby southern Indiana, which is also more forested that the SNF, cowbird parasitism rates are generally less than $20 \%$ for species such as Acadian Flycatcher and Wood Thrush (D. Whitehead pers. comm.). In these more forested landscapes, cowbird populations may be limited by the availability of feeding areas rather than host availability, the apparent limiting factor in the SNF (S.K.R. unpublished data). Interestingly, cowbirds may prefer searching for nests along edges in relatively unfragmented landscapes (F. $R$. Thompson pers. comm.). Radio-telemetry studies of cowbirds (e.g. Rothstein et al. 1984) in landscapes of differing degrees of fragmentation should shed light on cowbird use of habitat edges versus interior.

Extensive forests in other parts of the country also appear to have few problems with cowbird parasitism. Wilcove (1988) never saw or heard a cowbird in nine weeks of fieldwork in the 200,000 ha Great Smoky Mountains National Park. In the Hubbard Brook Experimental Forest, part of the mostly unfragmented White Mountains National Forest, only two incidences of parasitism have been recorded out of thousands of nests found by researchers over a 20-year period (Sherry and Holmes 1992). The few cowbirds in this predominantly forested landscape remain near farms and pastures (S.K.R. pers. obs.). Data on reproductive output of birds in the Hubbard Brook Forest can act as a baseline for comparisons with more fragmented landscapes.

Although we know that nest predation and brood-parasitism are important problems, we still do not know how to relate these effects directly to subsequent population changes. In spite of apparently low reproductive success, populations of Neotropical migrants persist in the fragmented forests of Illinois. Perhaps the birds nesting in SNF were born in more extensive forests hundreds of kilometres away, such as those in the Missouri Ozarks or the Hoosier National Forest. Populations in small woodlots may reflect regional dispersal patterns rather than local nesting success, which appears to dictate population changes 
in the unfragmented White Mountain National Forest (Sherry and Holmes 1992). Until we have better data on dispersal rates and distances, fecundity and juvenile and adult survivorship (May and Robinson 1985) in forests of different sizes and shapes, we cannot determine what levels of nest-parasitism and predation Neotropical migrants can tolerate. We believe that the major research need for the conservation of Neotropical migrants is demographic data. Perhaps genetic techniques will be developed to allow the identification of the geographical origin of dispersers colonizing fragmented woodlots.

\section{Silvicultural practices and fragmentation}

Many of the large forest tracts remaining in the eastern United States, especially in the Midwest and southern Appalachians, are managed by the federal government as part of the National Forest System. The national forests are managed under a multiple-use charter, which permits commercial logging, grazing and other extractive uses. Many people have expressed concern over the impact of logging on biological diversity in general and Neotropical migrants in particular. This concern, in turn, has caused the Forest Service and other federal agencies to undertake a major research and education effort entitled "Partners in Flight". This programme seeks to address some of the research needs identified above (see also Finch 1991) with special attention to silviculture.

In recent years the commonest method of logging in the national forests has been clear-cutting, in which all of the trees in a given area are removed. Clear-cutting eliminates the forest bird community from a stand until the regrowing saplings are large enough to support forest birds, a length of time that varies regionally and by bird species (Robbins 1979, Harris 1984). Thompson et al. (1992) found that areas subjected to clear-cutting had only slightly lower populations of most forest-nesting migrants than uncut areas because only a small percentage of the landscape consisted of early successional vegetation at any one time. Edges along clear-cuts and access roads may also contribute to increased nest predation and brood-parasitism (D. Whitehead pers. comm.). Clear-cutting also creates habitat for early successional species, most of which are regionally abundant, but some of which may be restricted to large areas of early successional habitat. Some researchers have recommended that clear-cuts be fewer in number, closer to existing edges, and larger in size to minimize the amount of edge created by logging and to provide larger, contiguous areas of early successional and mature forest habitat (Robbins 1979, Harris 1984).

An alternative method is selective logging, in which only a percentage of trees are taken out singly or in small "groups" at any one time. This method creates small canopy gaps that might mimic those found in old-growth forests. Selective logging can be a relatively low-volume harvesting method that does not significantly fragment the forest, but it may not provide habitat for species that require extensive early successional growth. Detailed studies of the impacts of selective logging vs. clear-cutting on Neotropical migrants are just now beginning.

In a study of the impact of selective logging (group and single-tree) on Neotropical migrants in the Trail of Tears State Forest, Illinois, S. K. Robinson and W. D. Robinson (unpublished data) have documented some impacts on forest 
birds. In this generally uniform forest, 20-30\% of the oak/hickory canopy was removed 2-13 years ago from four sections. Most Neotropical migrants were just as abundant in selectively logged sections as they were in uncut areas. Only the Red-eyed Vireo remained at low population densities 12 years after logging. A few forest species (e.g. Hooded Warbler) actually increased after selective logging and some early successional species were added to the community (e.g. White-eyed Vireo Vireo griseus, Indigo Bunting Passerina cyanea). These data suggest that most forest birds tolerate small forest gaps and some may require canopy openings. Cowbirds were more abundant and parasitism levels were somewhat higher in recent cuts. Cowbirds were especially common along logging roads where they fed.

Data on productivity of forest birds suggest that selectively logged areas do not suffer dramatic decreases in nesting success. In recent ( $\leqslant 3$ year) cuts, nest predation and parasitism rates varied greatly from species to species and year to year, possibly in response to rapidly changing vegetation structure. In cut areas, canopy-nesting species may suffer reduced nesting success, whereas ground- and shrub-nesting species may have increased nesting success in and under the rapidly regrowing understorey in canopy gaps. Older (10-13-year) cuts generally experience relatively low parasitism, but high predation rates. The results of this study, however, should be interpreted with great caution because they are based on only two years of data from a forested area where reproductive success is already very low due to saturated populations of cowbirds and nest predators. Studies of selective logging in less fragmented landscapes might show more dramatic differences. Similarly, the study areas have only been subjected to a single cutting cycle; a second cycle may have a greater impact on canopy-nesting species.

\section{Management recommendations}

We believe that forest fragmentation in eastern North America is a serious threat to Neotropical migrant populations. The high rates of nest predation and parasitism found in Illinois and southern Wisconsin (Temple and Cary 1988) may be extreme, but they provide a warning of what can happen if landscapes become too fragmented. The importance of protecting large, unfragmented forests for breeding habitat, therefore, cannot be overestimated. Predominantly forested landscapes contain abundant forest-interior habitat where Neotropical migrants can escape edge effects. The forest interior also provides few feeding opportunities for cowbirds and nest predators that benefit from the additional foods available in agricultural and urban areas.

(1) As many of these large forested areas on the breeding ground as possible should be protected from development, and logging should be excluded from at least some areas. Where possible, forest preserves should be on the order of $10,000+$ ha because cowbirds routinely commute up to $7 \mathrm{~km}$ between feeding and breeding sites. We do not, however, wish to imply that smaller woodlots are unimportant for the conservation of songbirds. Smaller woodlots provide migratory stopovers (Moore and Kerlinger 1987, Lindstrom 1989), places for surplus breeders to nest (Howe et al. 1991), and may even sustain source populations for species that hide their nests exceptionally well. 
(2) Fragmented forests such as the Shawnee National Forest might benefit from consolidation of ownership and forest regrowth within the largest tracts. The regional carrying capacity of cowbirds in southern Illinois may be high enough that even the largest tracts that could be created (c. 8,00o ha) would be saturated with cowbirds. If so, limited cowbird control might be tried within the core of the largest tracts.

(3) We tentatively propose that in areas where logging will take place, lowvolume single-tree selective logging should be tried in landscapes where cowbird parasitism is a potential problem. This recommendation needs to be validated by further research. We also recognize that vulnerability of Neotropical migrants to logging may vary regionally depending upon the extent of fragmentation (Thompson et al. 1992).

(4) Long rotations are preferable to short rotations. Long rotations produce the big, old trees that Cerulean Warblers Dendroica cerulea, Yellow-throated Vireos Vireo flavifrons, and a few other species prefer (Hands et al. 1989). Older forests are also more likely to display gap-phase dynamics important for species such as the Hooded Warbler. Protected core areas within forests subjected to logging, a practice recommended by Robbins (1979) and Harris (1984), might meet the habitat needs of old-growth specialists.

(5) Logging roads should be closed and revegetated as soon as possible, lest they provide foraging habitat for cowbirds and increased access to the forest interior for cowbirds and predators. If possible, logging roads should be narrow enough that they do not break the canopy. Campgrounds should also be managed to minimize extensive areas of grass where cowbirds can forage. Garbage must be removed quickly from campgrounds to avoid attracting raccoons, opossums and other potential nest predators.

(6) In landscapes where only a few species are suffering from reduced nesting success, species-specific management plans might be attempted. Cowbird control to protect endangered species (e.g. Black-capped Vireo Vireo atricapillus, Kirtland's Warbler Dendroica kirtlandii) is one example of such measures. It might also be possible to improve nesting habitat for individual species such as the Wood Thrush if vegetation patterns associated with successful reproduction can be accurately identified and duplicated through management, an approach advocated by Martin (1992).

\section{Acknowledgements}

First and foremost, we would like to thank the members of the field crews whose efforts have made this research possible. We are particularly grateful to Steve Bailey, Lonny Morse, Kris Bruner, Doug Robinson, Rhetta Jack and Cheri Trine who found the majority of the nests. Jeff Brawn, Ed Heske, John Faaborg and Robert Askins provided many useful comments when reviewing the manuscript. We also acknowledge the cooperation of Joe Newcomb, Mary Mumford, Mike Spanel and Rod Sallee of the U.S. Forest Service for allowing us to use the Dutch Creek Field Station. Funding for this research has come from the Illinois Department of Energy and Natural Resources, the U.S. Fish and Wildlife Service, the U.S. Forest Service, and the Illinois Department of Conservation. Finally, we thank Jim Seets and Elizabeth Anderson for logistical help. 


\section{References}

Alverson, W. S., Waller, D. M. and Solheim, S. L. (1988) Forests too deer: edge effects in northern Wisconsin. Conserv. Biol. 2: 348-358.

Ambuel, B. and Temple, S. A. (1982) Area-dependent changes in the bird communities and vegetation of southern Wisconsin forests. Ecology 64: 1057-1068.

Angelstam, P. (1986) Predation on ground-nesting birds' nests in relation to predator densities and habitat edge. Oikos 47: 365-373.

Askins, R. A. and Philbrick, M. J. (1987) Effects of changes in regional forest abundance on the decline and recovery of a forest bird community. Wilson Bull. 99: 7-21.

Askins, R. A., Philbrick, M. J. and Sugeno, D. (1987) Relationship between the regional abundance of forest and the composition of forest bird communities. Biol. Conserv. 39: 129-152.

Askins, R. A., Lynch, J. F. and Greenberg, R. (1990) Population declines in migratory birds in eastern North America. Pp.1-58 in D. M. Power, ed. Current ornithology, 7. New York, NY: Plenum Press.

Blake, J. and Karr, J. R. (1987) Breeding birds of isolated woodlots: area and habitat relationships. Ecology 68: 1724-1734.

Blondel, J. (1991) Birds in biological isolates. Pp.45-72 in C. M. Perrins, J. D. Lebreton and G. J. M. Hirons, èds. Bird population studies: relevance to conservation and management. Oxford, England: Oxford University Press.

Bond, R. R. (1957) Ecological distribution of breeding birds in the upland forests of southern Wisconsin. Ecol. Monogr. 27: 351-384.

Briggs, S. A. and Criswell, J. H. (1979) Gradual silencing of spring in Washington. Atlantic Nat. 32: 19-26.

Brittingham, M. C. and Temple, S. A. (1983) Have cowbirds caused forest songbirds to decline? BioScience 33: 31-55.

Brown, M. and Dinsmore, J. J. (1986) Implication of marsh size and isolation for marsh bird management. J. Wildl. Mgmt. 50: 392-397.

Elliott, P. F. (1978) Cowbird parasitism in the Kansas tallgrass prairie. Auk 95: 161-167.

Finch, D. M. (1991) Population ecology, habitat requirements, and conservation of Neotropical migratory birds. Fort Collins, CO: U.S. Department of Agriculture, Forest Service. Rocky Mountain Forest and Range Experiment Station (Gen. Techn. Rep. RM-205).

Freemark, K. and Collins, B. (1992) Landscape ecology of birds breeding in temperate forest fragments. Pp.443-454 in J. M. Hagan and D. W. Johnston, eds. Ecology and conservation of Neotropical migrant landbirds. Washington, D.C.: Smithsonian Institution Press.

Gates, J. E. and Gysel, L. W. (1978) Avian nest dispersion and fledging success in field-forest ecotones. Ecology 59: 871-883.

Gibbs, J. P. and Faaborg, J. (1990) Estimating the viability of Ovenbird and Kentucky Warbler populations in forest fragments. Conserv. Biol. 4: 193-196.

Hagan, J. M., Lloyd-Evans, T. L., Atwood, J. L. and Wood, D. S. (1992) Long-term changes in migratory landbirds in the northeastern United States: evidence from migration capture data. Pp.115-130 in J. M. Hagan and D. W. Johnston, eds. Ecology and conservation of Neotropical migrant landbirds. Washington, D.C.: Smithsonian Institution Press.

Hands, H. M., Drobney, R. D. and Ryan, M. R. (1989) Status of the Cerulean Warbler in the north-central United States. Twin Cities, MN: U.S. Fish and Wildlife Service.

Hanski, I. and Gilpin, M. (1991) Metapopulation dynamics: brief history and conceptual domain. Biol. J. Linnaean Soc. 42: 3-16.

Harris, L. D. (1984) The fragmented forest. Chicago, IL: University of Chicago Press.

Hayden, T. J., Faaborg, J. and Clawson, R. L. (1985) Estimates of minimum area requirements for Missouri forest birds. Trans. Missouri Acad. Sci. 19: 11-22. 
Holmes, R. T., Sherry, T. W. and Sturges, F. W. (1986) Bird community dynamics in a temperate deciduous forest: long-term trends at Hubbard Brook. Ecol. Monogr. 56: 201220.

Howe, R. W. (1984) Local dynamics of bird assemblages in small forest habitat islands in Australia and North America. Ecology 65: 1585-1601.

Howe, R. W., Davis, G. J. and Mosca, V. (1991) The demographic significance of "sink" populations. Biol. Conserv. 57: 239-255.

James, F. C., Wiedenfeld, D. A. and McCulloch, C. E. (1992) Trends in breeding populations of warblers: declines in the southern highlands and increases in the lowlands. Pp.43-56 in J. M. Hagan and D. W. Johnston, eds. Ecology and conservation of Neotropical migrant landbirds. Washington, D.C.: Smithsonian Institution Press.

Johnson, R. G. and Temple, S. A. (1986) Assessing habitat quality for birds nesting in fragmented tallgrass prairie. Pp.245-250 in J. Verner, M. L. Morrison and C. J. Ralph, eds. Wildlife 200o: modeling habitat relationships of terrestrial vertebrates. Madison, WI: University of Wisconsin Press.

Johnston, D. W. and Winings, D. I. (1987) Natural history of Plummers Island, Maryland. XXVII. The decline of forest breeding birds on Plummers Island, Maryland, and vicinity. Proc. Biol. Soc. Washington 100: 762-768.

Karr, J. R. (1982) Avian extinction on Barro Colorado Island, Panama: a reassessment. Amer. Nat. 119: 220-239.

Kendeigh, S. C. (1982) Bird populations in east central Illinois: fluctuations, variations, and development over a half century. Illinois Biol. Monogr. 52: 1-136.

Lindstrom, A. (1989) Finch flock size and risk of hawk predation at a migratory stopover site. Auk 106: 225-232.

Lynch, J. F. and Whigham, D. F. (1984) Effects of forest fragmentation on breeding bird communities in Maryland, U.S.A.. Biol. Conserv. 28: 287-324.

Martin, T. E. (1992) Breeding productivity considerations: what are the appropriate habitat features for management? Pp.455-473 in J. M. Hagan and D. W. Johnston, eds. Ecology and conservation of Neotropical migrant landbirds. Washington, D.C.: Smithsonian Institution Press.

May, R. M. and Robinson, S. K. (1985) Population dynamics of avian brood parasitism. Amer. Nat. 126: 475-494.

Mayfield, H. (1965) The Brown-headed Cowbird, with old and nęw hosts. Living Bird 4: 13-28.

Mayfield, H. (1975) Suggestions for calculating nest success. Wilson Bull. 87: 456-466.

Mayfield, H. (1977) Brown-headed Cowbirds: agent of extermination? Amer. Birds 31: 107-113.

Moore, F. R. and Kerlinger, P. (1987) Stopover and fat deposition by North American wood-warblers (Parulinae) following spring migration over the Gulf of Mexico. Oecologia 74: 47-54.

Pickett, S. T. A. and White, P. S. (1985) The ecology of natural disturbance and patch dynamics. New York, NY: Academic Press.

Pulliam, H. R. (1988) Sources, sinks, and population regulation. Amer. Nat. 132: 652661.

Pulliam, H. R. (1991) Sources, sinks, and habitat selection: a landscape perspective on population dynamics. Amer. Nat. 137: 550-66.

Ratti, J. T. and Reese, K. P. (1988) Preliminary test of the ecological trap hypothesis. $J$. Wildl. Mgmt. 52: 484-491.

Ray, C., Gilbin, M. and Smith, A. T. (1991) The effect of conspecific attraction on metapopulation dynamics. Biol. J. Linnaean Soc. 42: 123-134.

Ricklefs, R. E. (1973) Fecundity, mortality, and avian demography. Pp.366-434 in D. S. Farner, ed. Breeding biology of birds. Washington, D.C.: National Academy of Sciences. 
Robbins, C. S. (1979) Effect of forest fragmentation on bird populations. Pp.198-212 in R. M. DeGraaf and K. E. Evans, eds. Management of north-central and northeastern forests for nongame birds. St Paul, MN: U.S. Department of Agriculture, Forest Service, North Central Forest Experiment Station (Gen. Techn. Rep. NC-51).

Robbins, C. S., Bystrak, D. and Geissler, P. H. (1986) The breeding bird survey: its first 15 years, 1965-1979. U.S. Department of the Interior, Fish and Wildlife Service (Res. Publ. 157).

Robbins, C. S., Dawson, D. K. and Dowell, B. A. (1989a) Habitat area requirements of breeding forest birds of the Middle Atlantic States. Washington, D.C.: The Wildlife Society (Wildl. Monogr. 103).

Robbins, C. S., Sauer, J. R., Greenberg, R. and Droege, S. (1989b) Population declines of North American birds that migrate to the Neotropics. Proc. Natn. Acad. Sci. (U.S.A.) 86: $7658-7662$.

Robinson, S. K. (1988) Reappraisal of the costs and benefits of habitat heterogeneity for nongame wildlife. Trans. 53rd N.A. Wildl. Nat. Res. Conf.: 145-155.

Robinson, S. K. (1992) Population dynamics of breeding Neotropical migrants in a fragmented Illinois landscape. Pp.408-418 in J. M. Hagan and D. W. Johnston, eds. Ecology and conservation of Neotropical migrant landbirds. Washington, D.C.: Smithsonian Institution Press.

Root, R. B. (1967) The niche exploitation pattern of the blue-gray gnatcatcher. Ecol. Monogr. 37: 317-350.

Rothstein, S. I. (1975) Evolutionary rates and host defenses against avian brood parasitism. Amer. Nat. 109: 151-176.

Rothstein, S. I., Verner, J. and Stevens, E. (1984) Radio-tracking confirms a unique diurnal pattern of spatial occurrence in the parasitic Brown-headed Cowbird. Ecology 65: $77-78$.

Sherry, T. W. and Holmes, R. T. (1988) Habitat selection by breeding American Redstarts in response to a dominant competitor, the Least Flycatcher. Auk 105: 350-364.

Sherry, T. W. and Holmes, R. T. (1992) Population fluctuations in a long-distance Neotropical migrant: demographic evidence for the importance of breeding season events in the American Redstart. Pp.431-442 in J. M. Hagan and D. W. Johnston, eds. Ecology and conservation of Neotropical migrant landbirds. Washington, D.C.: Smithsonian Institution Press.

Small, M. F. and Hunter, M. L. (1988) Forest fragmentation and avian nest predation in forested landscapes. Oecologia 76: 62-64.

Smith, A. T. and Peacock, M. M. (1990) Conspecific attraction and the determination of metapopulation colonization rates. Conserv. Biol. 4: 320-323.

Soulé, M. E., Boulger, D. T., Alberts, A. C., Sauvojot, R., Wright, J., Sorice, M. and Hill, S. (1988) Reconstructed dynamics of rapid extinctions of chaparral-requiring birds in urban habitat islands. Conserv. Biol. 2: 75-92.

Stamps, J. A. (1988) Conspecific attraction and aggregation in territorial species. Amer. Nat. 131: 329-347.

Temple, S. A. and Cary, J. R. (1988) Modelling dynamics of habitat-interior bird populations in fragmented landscapes. Conserv. Biol. 2: 340-347.

Terborgh, J. (1989) Where have all the birds gone? Princeton: Princeton University Press.

Thompson, F. R., Dijak, W. D., Kulowiec, T. G. and Hamilton, D. A. (1992) Breeding bird populations in Missouri Ozark forests with and without clearcutting. J. Wildl. Mgmt. 56: 23-30.

Trine, C. L. Robinson, W. D. and Robinson, S. K. (in press) Consequences of Brownheaded Cowbird brood parasitism for host population dynamics. In S. I. Rothstein, ed. Avian brood parasitism. 
Villard, M.-A., Freemark, K. and Merriam, G. (1992) Metapopulation theory and Neotropical migrant birds in temperate forests: an empirical investigation. Pp.474-482 in J. M. Hagan and D. W. Johnston, eds. Ecology and conservation of Neotropical migrant landbirds. Washington, D.C.: Smithsonian Institution Press.

Whitcomb, R. F., Robbins, C. S., Lynch, J. F., Whitcomb, B. L., Klimkiewicz, K. and Bystrak, D. (1981) Effects of forest fragmentation on avifauna of the eastern deciduous forest. Pp.125-205 in R. L. Burgess and D. M. Sharpe, eds. Forest island dynamics in man-dominated landscapes. New York, NY: Springer-Verlag.

Wiens, J. A. (1989) The ecology of bird communities, 2: processes and variations. Cambridge, U.K.: Cambridge University Press.

Wilcove, D. S. (1985) Nest predation in forest tracts and the decline of migratory songbirds. Ecology 66: 1211-1214.

Wilcove, D. S. (1988) Changes in the avifauna of the Great Smoky Mountains: 19471983. Wilson Bull. 100: 256-271.

Wilcove, D. S. and Robinson, S. K. (1990) The impact of forest fragmentation on bird communities in eastern North America. Pp.319-331 in A. Keast, ed. Biogeography and ecology of forest bird communities. The Hague, Netherlands: SPB Academic Publishing.

Wilcove, D. S., McClellan, C. H. and Dobson, A. P. (1986) Habitat fragmentation in the temperate zone. Pp.237-256 in M. E. Soulé, ed. Conservation biology: the science of scarcity and diversity. Sunderland, MA: Sinauer Associates.

Yahner, R. (1988) Changes in wildlife communities near edges. Conserv. Biol. 2: 333-339.

Yahner, R. and Scott, D. P. (1988) Effects of forest fragmentation on depredation of artificial nests. J. Wildl. Mgmt. 52: 158-161.

SCOTT K. ROBINSON

Illinois Natural History Survey, 607 E. Peabody Drive, Champaign, IL 61820, U.S.A.

DAVID S. WILCOVE

Environmental Defense Fund, 1875 Connecticut Avenue N.W., Washington, D.C. 20009, U.S.A. 